\title{
Progesterone Receptor Measurement
}

National Cancer Institute

\section{Source}

National Cancer Institute. Progesterone Receptor Measurement. NCI Thesaurus. Code C117846.

The determination of the amount of progesterone receptor present in a sample. 